\title{
Too old to Shop? A Comparative Analysis of the Engagement of Junior and Senior Customers in Social Commerce
}

\author{
Xuequn Wang \\ Murdoch University \\ a.wang@murdoch.edu.au \\ Xiaolin Lin \\ West Texas A\&M University \\ xlin@wtamu.edu
}

\begin{abstract}
With the continuous success of social media websites also social commerce rises in popularity. As increasing numbers of elderly consumers use social media, it is interesting to understand how elderly consumers engage in social commerce platforms. This study examines how different dimensions of customer engagement influence trust with young and older consumers. A survey was conducted to collect data from American consumers.

Our results show that perceived enjoyment, satisfaction, and social commerce value have significant effects on consumers' trust. Further, there are important differences regarding the respective effects between younger and older consumers. Our study contributes to the literature by clarifying the effect of customer engagement on trust in social commerce between young and elderly consumers. Our results can provide practitioners important guidelines regarding how to support consumers' trust development in social commerce.
\end{abstract}

\section{Introduction}

Social commerce has become considerably popular in recent years. It refers to "any commercial activities facilitated by or conducted through the broad social media and Web 2.0 tools in consumers' online shopping processes or business' interactions with their customers" [1]. Social commerce platforms such as Facebook brand page have become important venues where consumers interact with each other and exchange product information and shopping experiences. According to a recent report ${ }^{1}, 45 \%$ of consumers share bad experiences, while $30 \%$ share good experiences via social media. The information shared on social commerce platforms will then

978-0-9981331-3-3

URI: https://hdl.handle.net/10125/64204

${ }^{1}$ https://www.zendesk.com/resources/customer-service-and-

\author{
Heiko Gewald \\ Neu-Ulm University of Applied Sciences \\ heiko.gewald@hs-neu-ulm.de
}

\author{
Catherine Prentice \\ Griffith University \\ c.prentice@griffith.edu.au
}

significantly influence other consumers' purchase decisions [2].

Recent literature has made important progress to understand consumers' activities and their impacts on decision-making in social commerce [e.g., 3, 4, 5]. In particular, one key conclusion from the literature is that social support and relationship quality are the primary determinants of consumers' social commerce activities $[4,6]$. Consumers have actively shared their product evaluations and shopping experience to support each other's decision-making. As such, researchers have given increasing attention to shopping outcomes that can benefit from social commerce. For example, Wang, Lin and Spencer [7] reported that consumers may receive a variety of benefits from social commerce, such as informed purchase decisions and enjoyable shopping experiences. Therefore, social commerce can be viewed an efficient approach to drive consumer purchase behaviors and improve business performance $[8,9]$.

On the other hand, there are still areas deserving more attention. First, few studies have examined the role of customer engagement. While previous studies have examined how various factors $[4,6]$ can facilitate consumes' participation in social commerce, there lack of systematic approach. The perspective of customer engagement can provide such an approach. As discussed below, the literature has proposed that customer engagement includes different dimensions, which can cover consumers' various aspects of participation in social commerce. Therefore, our first research objective is to examine how customer engagement influences consumers' experiences in social commerce platforms.

Previous literature has recognized that trust plays an essential role in e-commerce and social commerce because it can lead to important outcomes such as satisfaction and purchase [9, 10, 11]. Therefore, our study focuses on trust and examines how customer engagement influence trust development in social commerce.

Further, only few studies [e.g. 12, 13, 14] have explicitly examined how elderly consumers engage in 
online commerce activities (we found none dealing specifically with social commerce). Therefore, our second search objective is to examine how the effect of customer engagement differs between younger and older consumers.

Our study provides two important contributions to the literature. First, we identify relevant factors in different dimensions of customer engagement in social commerce. Second, our study shows how the effects of dimensions of customer engagement differ between younger and older consumers. The results of our study can provide practitioners important guidelines regarding how to manage social commerce platforms and enhance consumers' trust development.

The remaining paper is organized as follows. We first review the literature on social commerce, customer engagement, and elderly and IT. We then identify relevant factors in each dimension of customer engagement and develop our hypotheses. Then the research methodology is described, including data collection procedures, measures, data analysis and results. Finally, implication for theory and practice, limitations, and opportunities for future studies are discussed and the conclusion is drawn.

\section{Literature review}

\subsection{Social commerce}

Social commerce, as the interaction of social media and e-commerce, has gained popularity over the last years. It does not only provide good resources for consumers to improve purchase decisions, but also offers an innovative and efficient approach for companies to gain business value $[5,15,16]$. There is a demand to extend this stream of research and provide further insights into the phenomenon and its implementations for business practices. Scholars have attempted to study social commerce from various viewpoints. For example, Liang, Ho, Li and Turban [17] reported that social support and relationship quality can drive customers to share commercial information, which can serve important information sources for them to evaluate products and follow product recommendations. In another study, Zhang, Lu, Gupta and Zhao [6] elaborated how environmental stimuli can improve customers' usage experiences of social commerce, which can drive them to use social commerce for shopping purposes. Other scholars study consumers' social commerce behaviors from theoretical lenses such as social support theory [3] and trust transfer theory [18]. While these studies have made important progress, there is still a need to systematically examine how consumes' participation in social commerce can be facilitated by various factors. In the next section, we discuss the concept of customer engagement and how it can further the research of social commerce.

\subsection{Customer engagement}

Customer engagement is defined as customers' emotional, cognitive and behavioral involvement with the brand and its associated products $[19,20]$. Such engagement can result from satisfaction and commitment [21, 22]. Customer-engagement behaviors refer to a focus beyond purchasing such as providing referrals, spreading word-of-mouth (WOM) recommendations of a brand or product, and cocreating value for the firm or the brand with whom the customer chooses to engage [19, 21, 23, 24]. The concept of customer engagement has emerged as a key to achieving value co-creation and attracting brand loyalty. The popularization of social media has enhanced the level of customer engagement with a brand.

In social commerce, customer engagement refers to customers' interaction and cooperation with other consumers who are associated with the brand, manifested in members of social commerce platforms writing reviews, and providing support and information to other consumers [21, 22]. [25] indicate that customer engagement in social commerce has a positive influence on consumers who identify themselves with the brand. Online customer engagement is manifested in the help and support provided to other consumers through sharing information and experiences related to the brand, as well as in receiving support from other consumers. These engagement behaviors have implications for enhancing brand value for consumers and for reinforcing their brand loyalty [22].

As discussed above, customer engagement includes three dimensions: emotional, cognitive, and behavioral [19]. Therefore, the concept of customer engagement provides a systematical lens to understand how various factors from different dimensions facilitate consumers' participation in social commerce. Based on the literature, we identify important factors in each dimension in the context of social commerce. Specifically, we argue that the emotional dimension includes perceived enjoyment and satisfaction, the cognitive dimension includes social commerce value, and the behavioral dimension includes information seeking and sharing (please refer to "3. Research model and hypotheses development" section for more details).

Further, few studies have attempted to understand the generation differences in online customer engagement. [26] show that different generations vary in their use of social media. [27] found that age differences had impact on mobile service perceptions of generation Y (those born between 1980s and early 2000s) and baby boomers (those born between 1946 and 1964). This study informs that age does play a role in the level of customer engagement with the brand in social commerce.

Page 3781 


\subsection{Elderly and IT}

Apart from common misperceptions, seniors are not all a large segment of tech-adverse people. On the contrary, the segment of the elderly is diverse and ranges from tech-affine to tech-adverse [28]. Thus, even though many seniors already make use of IT there are still difference in use and behavior.

Elderly people make use of IT and specifically the internet and they develop the necessary capabilities. however, there is still a difference in use patterns compared to younger segments: With the increasing penetration of internet and IT access in our society, all demographics are able to acquire capabilities to use all kinds of information technology. However, research has shown that among segments of people, there is still a divide in use and outcome [29]. Even though people have access, ways in which individuals use given IT differ, which is especially the case in the segment of older people. Older people or seniors are more prone to use traditional media. The do not use the internet as a source of information as much as younger people when it comes to health knowledge [30]. While $75 \%$ of the people between the age of 18 and 64 use the internet to get health knowledge, only $58 \%$ of seniors do so.

Leung, Tang, Haddad, Mcgrenere, Graf and Ingriany [31] state that older adults above 65 have difficulties to learn the use of mobile devices. However, there are seniors who already make plenty use of mobile devices. To date, little is known about whether use of different kinds of devices influences the urge to explore new ways in using IT. The use of mobile devices also implicates the adoption of new services and digital resources. The HICCS minitrack on Seniors' Use of Digital Resources addresses this topic and its implications for several years now (see e.g. [32]).

However, despite much research progress over the last years, the area of senior shopping behavior, specifically with respect to social commerce has been neglected. We were not able to identify published work addressing this topic with specific respect to implications of IT.

\section{Research model and hypotheses development}

For our study we selected trust as the dependent variable. Trust is defined as "the willingness of a party (trustor) to be vulnerable to the actions of another party (trustee) based on the expectation that the other (trustee) will perform a particular action important to the trustor, irrespective of the ability to monitor or control that other party (trustee)" [33]. On social commerce platforms, consumers are trustors and platforms are trustees. Our research model is depicted in Figure 1. In the following, we describe our constructs and hypotheses in more details.

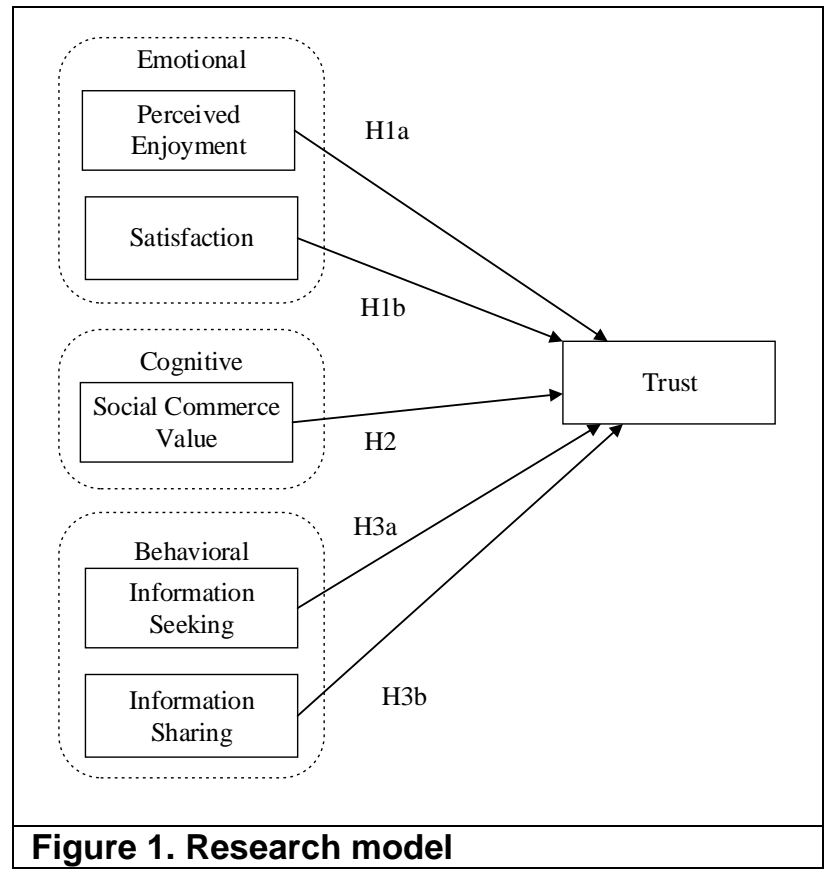

\subsection{Emotional engagement and trust}

We argue that the emotional dimension of customer engagement includes perceived enjoyment and satisfaction. Perceived enjoyment refers to "the extent to which the activity of using the computer is perceived to be enjoyable in its own right, apart from any performance consequences that may be anticipated" [34]. In this study, using computers refers to engagement on social commerce platforms. According to [35], people will experience flow when they enjoy doing certain activities. When consumers enjoy engaging with others on social commerce platforms, they will experience flow. In such a scenario, they probably perceive that social platforms provide an enjoyable environment and operate reliably for them to interact with other consumers. In other words, consumers will perceive that social platforms act in their interest to support their enjoyable engagement. Therefore, we hypothesize that:

H1a: Perceived enjoyment is positively related to trust.

Satisfaction has been examined as an emotional or cognitive construct in the literature [36, 37]. Oliver [38] argues that emotion "coexists alongside various cognitive judgments in producing satisfaction" (p. 319). Therefore, our study focuses on emotional satisfaction and define it as "the summary psychological state resulting when the emotion surrounding disconfirmed expectations is coupled with consumer's prior feelings" about social commerce platforms [39]. Previous literature has shown that satisfaction can enhance relationship quality and customer loyalty [37]. When consumers engage in social commerce platforms, various emotions can be 
generated. When consumers display positive emotions, they probably perceive that social commerce platforms are conformable environments and are willing to become more vulnerable, leading to a higher level of trust. Therefore, we hypothesize that:

H1b: Satisfaction is positively related to trust.

\subsection{Cognitive engagement and trust}

Our study focuses on social commerce value as the cognitive dimension of customer engagement. Social commerce value refers to the value that customers derive from engaging in social commerce platforms. Social commerce platforms provide user-generated content (UGC) [40] for consumers to evaluate products/services. In other words, UGC can fulfil customers' needs for acquiring product information and making informed decisions [7]. Besides, consumers can receive product offers and monetary savings [41] from these platforms. When consumes perceive that social commerce platforms are reliable channels to obtain product/service information and [42] and to receive savings, they probably perceive that these platforms act in their interests, enhancing their trust. Therefore, we hypothesize that:

$\mathrm{H} 2$ : Social commerce value is positively related to trust.

\subsection{Behavioral engagement and trust}

Our study proposes information seeking and sharing as the behavioral dimension of customer engagement. In the pre-purchase stage, consumers engage in social commerce platforms to obtain product-related information. Social commerce platforms contain a variety of information generated by firms and other consumers, such as product quality, usage experiences, and product feedbacks. The information has an important impact on consumers' purchase decisions [2] and has become an important avenue for consumers to evaluate products and make their purchase decisions. In the post-purchase stage, consumers have been engaging in social commerce platforms by sharing product-related information, such as their shopping experiences, product reviews, recommendations to other consumers $[43,44]$.

Therefore, consumers can play the role of information seeker and information provider, and social commerce platforms have a create an innovative environment supporting consumers' interactions with each other during different stages of purchase processes. As consumers regularly participate in information seeking and sharing on social commerce platforms, they probably form their perception that these platforms are reliable sites to support their interactions and purchase processes, enhancing their trust. Therefore, we hypothesize that:
H3a: Information seeking is positively related to trust.

$\mathrm{H} 3 \mathrm{~b}$ : Information sharing is positively related to trust.

\section{Method}

Data were collected from a survey taken by American consumers. Below we describe our data collection procedures, measurements, data analysis, and results.

\subsection{Data collection and sample}

Facebook brand page, a popular social commerce site [45], was selected as the context of this study. A survey company maintaining national panels was employed to recruit participants. The invitations for the survey were sent to consumers from national panels using systematic sampling. Participants were qualified for the survey when they 1) used Facebook many times a week, and 2) followed certain brand page(s) on Facebook (with frequent visits). Participants were then instructed to complete the survey based on their experiences of their favorite brand page(s).

In total, we received 274 valid responses from the group of young consumers and 266 valid responses from the group of elderly consumers. In this study we consider those less than 40 years as young consumers (i.e., "digital natives" born after 1980) [46, 47] and those more than 60 years as elderly consumers.

Our data shows that participants followed a variety of brands, including Amazon, Coca-Cola, Giorgio Armani, Macy's, Nike, and Pepsi. Participants' demographic information is shown in Table 1.

Table 1. Sample Demographic Information

\begin{tabular}{|l|c|c|}
\hline Category & Young & Elderly \\
\hline Ethnicity & & \\
\hline White & $70.3 \%$ & $90.0 \%$ \\
\hline Black or African American & $13.0 \%$ & $5.9 \%$ \\
\hline $\begin{array}{l}\text { American Indian or Alaska } \\
\text { Native }\end{array}$ & $.7 \%$ & $.7 \%$ \\
\hline Asian & $8.3 \%$ & $.7 \%$ \\
\hline Hispanic & $6.5 \%$ & $1.9 \%$ \\
\hline Other & $1.1 \%$ & $.7 \%$ \\
\hline Education & & \\
\hline Less than high school & $.7 \%$ & $1.5 \%$ \\
\hline High school graduate & $15.9 \%$ & $21.9 \%$ \\
\hline Some college & $25.4 \%$ & $27.8 \%$ \\
\hline 2-year degree & $15.2 \%$ & $13.7 \%$ \\
\hline 4-year degree & $34.1 \%$ & $22.6 \%$ \\
\hline Professional degree & $8.0 \%$ & $11.9 \%$ \\
\hline Doctorate & $.7 \%$ & $.7 \%$ \\
\hline Gender (\% of Female) & $56.9 \%$ & $70.0 \%$ \\
\hline Years visiting Facebook & 6.55 & 4.93 \\
\hline $\begin{array}{l}\text { Years visiting Facebook brand } \\
\text { page }\end{array}$ & 3.21 & 2.31 \\
\hline
\end{tabular}




\subsection{Measures}

Our measures (Table 2) were adapted from previous literature. Specifically: items of perceived enjoyment were adapted from [48]; items of satisfaction were adapted from [49]; items of social commerce value were adapted from [41] and [50]; items of trust were adapted from [17]. The items were rated on a 7-point Likert scale, ranging from "Strongly Disagree" to "Strongly Agree." Items of information seeking and sharing were adapted from [17]. These items were rated on a 7-point Likert scale, ranging from "Never" to "Always."

\section{Table 2. Measures}

Perceived Enjoyment

I find my use of my favorite Facebook brand page

PE1: interesting

PE2: entertaining

PE3: enjoyable

PE4: pleasant

PE5: fun

Satisfaction

How do you feel about your overall experience of using your favorite Facebook brand page

SAT1: satisfied

SAT2: pleased

SAT3: content

SAT4: delighted

Social commerce Value

I believe because of using my favorite Facebook brand page in my online shopping:

SCV1: I find online shopping is more interesting than I expected.

SCV2: I find online shopping is more enjoyable than I expected.

SCV3: I find it easier to make more informed and accurate purchase decisions.

SCV4: I find the information available to me meets my needs adequately in my purchase decisions.

SCV5: I find more ways to receive product promotions and discounts.

Information Seeking

Please choose your usage frequency for each of the following when using Facebook

ISE1: View Facebook Fan Pages

ISE2: Like product/brand-related posts

ISE3: Link to product / brand-related posts

ISE4: Read product reviews and user comments

\section{Information Sharing}

Please choose your usage frequency for each of the

following when using Facebook

ISH1: Write product / brand-related comments

ISH2: Share shopping experiences and suggestions

ISH3: Share product / brand related posts
ISH4: Recommend brand pages

Trust

TIF1: The performance of Facebook always meets my expectations.

TIF2: Facebook can be counted on as a good site.

TIF3: Facebook is a reliable site.

\subsection{Data analysis and results}

Because all the variables were collected in one survey, we first assessed the potential threat of common method bias (CMB) [51]. First, a Harmon one-factor analysis was conducted. The exploratory factor analysis extracted six factors explaining $79.80 \%$ of the variance, and the amount of variance explained by the first factor is $44.83 \%$. We then assessed CMB with a marker-variable technique [52]. A marker variable was used as a surrogate for method variance to partial out method bias. After adjustment, all the significant correlations remained significant. Therefore, we concluded that CMB was probably not a serious concern.

Our model was tested with partial least squares (PLS). SmartPLS was used with the bootstrap resampling method (using 1,000 samples) to determine the significance of the paths [53]. We used PLS because our measurements were not normally distributed and Shapiro-Wilk tests were significant. According to [54], PLS is more appropriate with nonnormally distributed data.

First, we evaluated the measurement model. As shown in Table 3, each item loaded significantly on its respective construct, with none of the factor loadings (FLs) below .50 [55]. The composite reliabilities (CRs) were over .70 , and the average variance extracted (AVE) was over .50. Therefore, convergent validity was supported. Discriminant validity was also confirmed by ensuring that the correlations between constructs were below .85 [56]. For each construct, the square root of its AVE exceeded all correlations between that factor and any other construct (Table 4). Therefore, our measures demonstrated good psychometric properties. Further, all the VIF values were less than the threshold of 5 [57], suggesting that multicollinearity is not a serious problem in our study. 
Table 3. Item Descriptive Information

\begin{tabular}{|c|c|c|c|c|c|c|}
\hline & \multicolumn{3}{|c|}{ Young } & \multicolumn{3}{c|}{ Elderly } \\
\hline Item & FL & CR & AVE & FL & CR & AVE \\
\hline PE1 & .87 & .95 & .80 & .89 & .97 & .86 \\
\hline PE2 & .86 & & & .92 & & \\
\hline PE3 & .92 & & & .96 & & \\
\hline PE4 & .90 & & & .94 & & \\
\hline PE5 & .91 & & & .92 & & \\
\hline SAT1 & .90 & .95 & .82 & .95 & .97 & .80 \\
\hline SAT2 & .91 & & & .96 & & \\
\hline SAT3 & .94 & & & .96 & & \\
\hline SAT4 & .90 & & & .92 & & \\
\hline SCV1 & .90 & .96 & .81 & .95 & .97 & .87 \\
\hline SCV2 & .92 & & & .95 & & \\
\hline SCV3 & .91 & & & .95 & & \\
\hline SCV4 & .91 & & & .93 & & \\
\hline SCV5 & .87 & & & .89 & & \\
\hline ISE1 & .79 & .92 & .74 & .67 & .90 & .68 \\
\hline ISE2 & .91 & & & .88 & & \\
\hline ISE3 & .89 & & & .91 & & \\
\hline ISE4 & .84 & & & .84 & & \\
\hline ISH1 & .91 & .96 & .86 & .92 & .96 & .87 \\
\hline ISH2 & .92 & & & .95 & & \\
\hline ISH3 & .95 & & & .94 & & \\
\hline ISH4 & .94 & & & .93 & & \\
\hline TIF1 & .85 & .91 & .78 & .92 & .96 & .89 \\
\hline TIF2 & .91 & & & .96 & & \\
\hline TIF3 & .88 & & & .95 & & \\
\hline
\end{tabular}

Table 4. Correlation between constructs and square-root of AVEs (on diagonal)

\begin{tabular}{|l|c|c|c|c|c|c|}
\hline Young & 1 & 2 & 3 & 4 & 5 & 6 \\
\hline $\begin{array}{l}\text { 1 Information } \\
\text { Seeking }\end{array}$ & $\mathbf{. 8 6}$ & & & & & \\
\hline $\begin{array}{l}\text { 2 Information } \\
\text { Sharing }\end{array}$ & .81 & $\mathbf{. 9 3}$ & & & & \\
\hline $\begin{array}{l}\text { 3 Perceived } \\
\text { Enjoyment }\end{array}$ & .37 & .27 & $\mathbf{. 9 9}$ & & & \\
\hline 4 Satisfaction & .31 & .24 & .80 & $\mathbf{. 9 1}$ & & \\
\hline $\begin{array}{l}\text { 5 Social Commerce } \\
\text { Value }\end{array}$ & .44 & .46 & .50 & .51 & $\mathbf{. 9 0}$ & \\
\hline 6 Trust & .45 & .41 & .57 & .56 & .57 & $\mathbf{. 8 8}$ \\
\hline Elderly & 1 & 2 & 3 & 4 & 5 & 6 \\
\hline $\begin{array}{l}\text { 1 Information } \\
\text { Seeking }\end{array}$ & $\mathbf{. 3 3}$ & & & & & \\
\hline $\begin{array}{l}\text { 2 Information } \\
\text { Sharing }\end{array}$ & .75 & $\mathbf{. 9 3}$ & & & & \\
\hline $\begin{array}{l}\text { 3 Perceived } \\
\text { Enjoyment }\end{array}$ & .48 & .45 & $\mathbf{. 9 3}$ & & & \\
\hline 4 Satisfaction & .38 & .40 & .80 & $\mathbf{. 9 5}$ & & \\
\hline $\begin{array}{l}\text { 5 Social Commerce } \\
\text { Value }\end{array}$ & .38 & .41 & .40 & .39 & $\mathbf{. 9 4}$ & \\
\hline 6 Trust & .35 & .34 & .53 & .56 & .44 & $\mathbf{. 9 4}$ \\
\hline
\end{tabular}
customer engagement influence trust in social commerce. We find that perceived enjoyment, satisfaction, and social commerce value have significant effects on trust. Further, there are interesting differences between younger and older consumers.

\subsection{Implications for theory}

Our study makes two main theoretical contributions. First, we identify relevant factors within the dimensions of customer engagement. Based on the literature, our study identifies perceived enjoyment and satisfaction as the emotional dimension, social commerce value as the cognitive dimension, and information seeking/sharing as the behavioral dimension. We find that perceived enjoyment, satisfaction, and social commerce value have significant effects on consumers' trust. Thus, our study contributes to the literature by clarifying the effect of customer engagement on trust in social commerce.

Second, our study finds that there are important differences regarding the effect of customer engagement between young and elderly consumers. Specifically, perceived enjoyment and social commerce value play a more important role for young 
consumers, while elderly consumers emphasize more on satisfaction during their formation of trust. Our study thus contributes to the literature by showing how young and elderly consumers engage in social commerce differently.

\subsection{Implications for practice}

Our study also indicates notable practical implications. First, satisfaction and social commerce value support trust development for both young and old consumers. Therefore, firms and platform providers of social commerce need to focus on these two factors to support consumers' development of trust. As satisfaction has a larger effect for elderly consumers, practitioners need to pay attention to satisfaction when interacting with elderly consumers.

On the other hand, social commerce value has a stronger effect for young consumers. Therefore, firms need to ensure that young consumers can receive good value by engaging in social commerce. For example, platform providers can highlight those highly rated/liked posts on platforms. Young consumers could also be encouraged to provide feedbacks on firmgenerated posts so that firms can improve these posts and help consumers derive more value.

Lastly, perceived enjoyment has a significant effect for young consumers. Therefore, platform providers and firms need to collaborate to make young consumers feel enjoyed while engaging in social commerce platforms. For example, firms can post interesting pictures and videos of their products. They can also integrate some interesting small games related to their business into social commerce platforms.

\subsection{Limitations and opportunities for future studies}

Our findings are prone to some limitations. First, our participants were recruited by the survey company, so our sample may be biased towards respondents who like to engage in panel activities. Second, we were only able to analyze American consumers, and our results may not generalize to consumers from other cultural backgrounds. Third, we focus on one particular social commerce platforms. Future studies are needed to examine whether our results still hold in other social commerce platforms.

Future research may extend our study in several ways. First, other factors belong to different dimensions of customer engagement can be examined. Second, moderators may be influenced to examine how they moderate the relationship between customer engagement and trust. Third, other important outcome variables (e.g., word of mouth, purchase intention) should be examined. Lastly, future studies can investigate the role of emotion/health/lifestyle more directly in elderly consumers' engagement in social commerce platforms.

\section{Conclusion}

As social commerce becomes ever more poplar, it is important to understand the effect of customer engagement, especially for the growing user group of senior consumers. Based on the survey data collected from American consumers, our study shows that dimensions of customer engagement have significant effects on trust, and there are important differences between young and elderly consumers. Future studies are needed to examine elderly consumers' engagement by incorporating other important factors.

\section{References}

[1] Lin, X., Li, Y., and Wang, X., "Social commerce research: Definition, research themes and the trends", International Journal of Information Management, 37(3), 2017, pp. 190-201.

[2] Trusov, M., Bucklin, R.E., and Pauwels, K., "Effects of word-of-mouth versus traditional marketing: findings from an internet social networking site", Journal of Marketing, 73(5), 2009, pp. 90-102.

[3] Hajli, M.N., "The role of social support on relationship quality and social commerce", Technological Forecasting and Social Change, 87(2014, pp. 17-27.

[4] Liang, T.-P., and Turban, E., "Introduction to the special issue social commerce: a research framework for social commerce", International Journal of Electronic Commerce, 16(2), 2011, pp. 5-14.

[5] Ng, C.S.-P., "Intention to purchase on social commerce websites across cultures: A cross-regional study", Information \& Management, 50(8), 2013, pp. 609-620.

[6] Zhang, H., Lu, Y., Gupta, S., and Zhao, L., "What motivates customers to participate in social commerce? The impact of technological environments and virtual customer experiences", Information \& Management, 51(8), 2014, pp. 1017-1030.

[7] Wang, X., Lin, X., and Spencer, M.K., "Exploring the effects of extrinsic motivation on consumer behaviors in social commerce: Revealing consumers' perceptions of social commerce benefits", International Journal of Information Management, 45(2019, pp. 163-175.

[8] Hu, T., Dai, H., and Salam, A., "Integrative qualities and dimensions of social commerce: Toward a unified view", Information \& Management, 2018.

[9] Lin, X., Wang, X., and Hajli, N., "Building E-commerce Satisfaction and Boosting Sales: the role of social commerce trust and its antecedents", International Journal of Electronic Commerce, 2019.

[10] Kim, D.J., Ferrin, D.L., and Rao, H.R., "Trust and satisfaction, two stepping stones for successful ecommerce relationships: A longitudinal exploration", Information systems research, 20(2), 2009, pp. 237 257.

[11] Mcknight, D.H., Choudhury, V., and Kacmar, C., "The impact of initial consumer trust on intentions to transact with a web site: a trust building model", The journal of strategic information systems, 11(3-4), 2002, pp. 297-323.

[12] Hernández, B., Jiménez, J., and José Martín, M., "Age, gender and income: do they really moderate online shopping behaviour?", Online information review, 35(1), 2011, pp. 113-133. 
[13] Iyer, R., and Eastman, J.K., "The elderly and their attitudes toward the internet: the impact on internet use, purchase, and comparison shopping", Journal of Marketing Theory and Practice, 14(1), 2006, pp. 57-67.

[14] Smith, T.J., "Senior citizens and e-commerce websites: The role of perceived usefulness, perceived ease of use, and web site usability", Informing Science, 11(2008.

[15] Zhang, K.Z., Benyoucef, M., and Zhao, S.J., "Building brand loyalty in social commerce: The case of brand microblogs", Electronic Commerce Research and Applications, 15(2016, pp. 14-25.

[16] Chong, A.Y.L., Lacka, E., Boying, L., Chan, H.K.J.I., and Management, "The role of social media in enhancing guanxi and perceived effectiveness of Ecommerce institutional mechanisms in online marketplace", 55(5), 2018, pp. 621-632.

[17] Liang, T.-P., Ho, Y.-T., Li, Y.-W., and Turban, E., "What drives social commerce: The role of social support and relationship quality", International Journal of Electronic Commerce, 16(2), 2011, pp. 69-90.

[18] Liu, L., Lee, M.K., Liu, R., and Chen, J., "Trust transfer in social media brand communities: The role of consumer engagement", International Journal of Information Management, 41(2018, pp. 1-13.

[19] Brodie, R.J., Hollebeek, L.D., Jurić, B., and Ilić, A., "Customer engagement: Conceptual domain, fundamental propositions, and implications for research", Journal of service research, 14(3), 2011, pp. 252-271.

[20] Hollebeek, L.D., "Demystifying customer brand engagement: Exploring the loyalty nexus", Journal of Marketing Management, 27(7-8), 2011, pp. 785-807.

[21] Van Doorn, J., Lemon, K.N., Mittal, V., Nass, S., Pick, D., Pirner, P., and Verhoef, P.C., "Customer engagement behavior: theoretical foundations and research directions", Journal of service research, 13(3), 2010, pp. 253-266.

[22] Algesheimer, R., Dholakia, U.M., and Herrmann, A., "The social influence of brand community: Evidence from European car clubs", Journal of Marketing, 69(3), 2005, pp. 19-34.

[23] Hoyer, W.D., Chandy, R., Dorotic, M., Krafft, M., and Singh, S.S., "Consumer cocreation in new product development", Journal of service research, 13(3), 2010, pp. 283-296.

[24] Nambisan, S., and Nambisan, P., "How to profit from a better'virtual customer environment'", MIT Sloan management review, 49(3), 2008, p 53.

[25] Wirtz, J., Den Ambtman, A., Bloemer, J., Horváth, C., Ramaseshan, B., Van De Klundert, J., Gurhan Canli, Z., and Kandampully, J., "Managing brands and customer engagement in online brand communities", Journal of Service Management, 24(3), 2013, pp. 223 244.

[26] Bolton, R.N., Parasuraman, A., Hoefnagels, A., Migchels, N., Kabadayi, S., Gruber, T., Komarova Loureiro, Y., and Solnet, D., "Understanding Generation $\mathrm{Y}$ and their use of social media: a review and research agenda", Journal of Service Management, 24(3), 2013, pp. 245-267.

[27] Kumar, A., and Lim, H., "Age differences in mobile service perceptions: comparison of Generation $\mathrm{Y}$ and baby boomers", Journal of Services Marketing, 22(7), 2008, pp. 568-577.

[28] Tams, S., Grover, V., and Thatcher, J., "Modern information technology in an old workforce: toward a strategic research agenda", The journal of strategic information systems, 23(4), 2014, pp. 284-304.

[29] Wei, K.-K., Teo, H.-H., Chan, H.C., and Tan, B.C., "Conceptualizing and testing a social cognitive model of the digital divide", Information Systems Research, 22(1), 2011, pp. 170-187.

[30] Nimrod, G., "Older audiences in the digital media environment", Information, Communication \& Society, 2016, pp. 1-17.

[31] Leung, R., Tang, C., Haddad, S., Mcgrenere, J., Graf, P., and Ingriany, V., "How Older Adults Learn to Use Mobile Devices: Survey and Field Investigations", ACM Trans. Access. Comput., 4(3), 2012, pp. 1-33.

[32] Gewald, H., Vogel, D., and Bozan, K., "Introduction to the Minitrack on Seniors' Use of Digital Resources", Proceedings of the 52nd Hawaii International Conference on System Sciences, 2019

[33] Mayer, R.C., Davis, J.H., and Schoorman, F.D., "An integrative model of organizational trust", Academy of management review, 20(3), 1995, pp. 709-734.

[34] Davis, F.D., Bagozzi, R.P., and Warshaw, P.R., "Extrinsic and Intrinsic Motivation to Use Computers in the Workplace", Journal of Applied Social Psychology, 22(14), 1992, pp. 1111-1132.

[35] Csikszentmihalyi, M., Flow: The psychology of optimal performance, Cambridge University Press, New York, NY, 1990.

[36] Babin, B.J., and Griffin, M., "The nature of satisfaction: an updated examination and analysis", Journal of Business Research, 41(2), 1998, pp. 127-136.

[37] Wong, A., "The role of emotional satisfaction in service encounters", Managing Service Quality: An International Journal, 14(5), 2004, pp. 365-376.

[38] Oliver, T.A., Satisfaction: A Behavioral Perspective on the Consumer, Irwin McGraw-Hill, Boston, MA, 1997.

[39] Oliver, R.L., "Measurement and evaluation of satisfaction processes in retail settings", Journal of retailing, 1981.

[40] Wang, X., and Li, Y., "How trust and need satisfaction motivate producing user-generated content", Journal of Computer Information Systems, 57(1), 2017, pp. 49-57.

[41] Chiu, C.M., Wang, E.T., Fang, Y.H., and Huang, H.Y., "Understanding customers' repeat purchase intentions in $\mathrm{B} 2 \mathrm{C} \mathrm{e}$-commerce: the roles of utilitarian value, hedonic value and perceived risk", Information Systems Journal, 24(1), 2014, pp. 85-114.

[42] Shin, D.-H., "User experience in social commerce: in friends we trust", Behaviour \& information technology, 32(1), 2013, pp. 52-67.

[43] Hudson, S., Roth, M.S., Madden, T.J., and Hudson, R., "The effects of social media on emotions, brand relationship quality, and word of mouth: An empirical study of music festival attendees", Tourism Management, 47(2015, pp. 68-76.

[44] Zheng, X., Cheung, C.M., Lee, M.K., and Liang, L., "Building brand loyalty through user engagement in online brand communities in social networking sites", Information Technology \& People, 28(1), 2015, pp. 90106.

[45] Prentice, C., Wang, X., and Lin, X., "An organic approach to customer engagement and loyalty", Journal of Computer Information Systems, 2018, pp. 1-10.

[46] Liu, Z., Wang, X., and Liu, J., "How digital natives make their self-disclosure decisions: a cross-cultural comparison", Information Technology \& People, 2018. 
[47] Prensky, M., "Digital natives, digital immigrants part 1", On the horizon, 9(5), 2001, pp. 1-6.

[48] Van Der Heijden, H., "User acceptance of hedonic information systems", MIS quarterly, 2004, pp. 695704.

[49] Bhattacherjee, A., "Understanding information systems continuance: an expectation-confirmation model", MIS quarterly, 2001, pp. 351-370.

[50] Jones, M.A., Reynolds, K.E., and Arnold, M.J., "Hedonic and utilitarian shopping value: Investigating differential effects on retail outcomes", Journal of Business Research, 59(9), 2006, pp. 974-981.

[51] Podsakoff, P.M., Mackenzie, S.B., Lee, J.-Y., and Podsakoff, N.P., "Common method biases in behavioral research: A critical review of the literature and recommended remedies", Journal of applied psychology, 88(5), 2003, p 879.

[52] Lindell, M.K., and Whitney, D.J., "Accounting for common method variance in cross-sectional research designs", Journal of applied psychology, 86(1), 2001, p 114.

[53] Ringle, C.M., Wende, S., and Will, S., "SmartPLS 2.0 (M3) Beta, Hamburg 2005", 2005

[54] Hair Jr, J.F., Hult, G.T.M., Ringle, C., and Sarstedt, M., A primer on partial least squares structural equation modeling (PLS-SEM), Sage publications, 2016.

[55] Hulland, J., "Use of partial least squares (PLS) in strategic management research: a review of four recent studies", Strategic management journal, 20(2), 1999, pp. 195-204.

[56] Brown, T.A., Confirmatory factor analysis for applied research, Guilford Publications, 2014.

[57] Rogerson, P.A., Statistical methods for geography: a student's guide, Sage, 2014.

[58] Keil, M., Tan, B.C., Wei, K.-K., Saarinen, T., Tuunainen, V., and Wassenaar, A., "A cross-cultural study on escalation of commitment behavior in software projects", MIS quarterly, 2000, pp. 299-325. 